Annals of Plant and Soil Research 22(4): 380-385 (2020)

https://doi.org/10.47815/apsr.2020.10008

\title{
Differential responses to iron stress in blackgram (Vigna mungo L.) varieties
}

\section{SANGITA DEY, PREETOM REGON, BHABEN CHOWARDHARA AND SANJIB KUMAR PANDA*}

\author{
Plant Molecular Biotechnology Laboratory, Department of Life Science and Bioinformatics, Assam \\ University, Silchar (Assam)-788011. India
}

Received: July, 2020; Revised accepted: September, 2020

\begin{abstract}
The intention behind conducting this study was to evaluate the toxicological response of black gram (Vigna mungo) varieties exposed to iron stress at an early seedling stage. Iron is a micronutrient required to plant for various metabolic activity. However, its toxicity or deficiency can cause harmful effects to the plants. The experiment was conducted in the Department of Life Science and Bioinformatics of Assam University, Silchar during kharif season of 2019. Two blac gram varieties and three iron concentrations (control, 10 $\mu \mathrm{M}$ and $2 \mathrm{mM}$ ) were evaluated in laboratory conditions. The results clearly showed that significant difference was observed in the growth of roots and shoots and total biomass of the plants grown in three different iron conditions. An enhancement was observed in $\mathrm{MDA}, \mathrm{H}_{2} \mathrm{O}_{2}$, and $\mathrm{O}_{2}^{-}$and in IPU-073 than in Shekhar-1. At irondeficiency, $\mathrm{H}_{2} \mathrm{O}_{2}, \mathrm{MDA}, \mathrm{O}_{2}^{-}$radical content of IPU-073 increased by 88.3, 79 and 50.1\% whereas, in Shekhar-1, it increased by 70.5, 26.8 and $36.6 \%$ in roots respectively which was found to be higher than Fe-excess condition in both roots and shoots. The reduction rate of Chlorophyll content was lower in Shekhar-1 (9.1\%) than IPU 073 (31.8\%). The comparison between these two varieties showed that Shekhar-1 performed better than IPU-073 under different iron stress condition.
\end{abstract}

Key words: Iron excess, iron deficiency, blackgram, oxidative stress, ROS

\section{INTRODUCTION}

Black gram(Vigna mungoL.) is an important pulse legume considered as a staple food which is domestically grown and has various industrial uses and possess the ability to resist adverse climatic conditions. Undoubtedly, black gram contributes in nitrogen requirement in the soil by fixing atmospheric nitrogen as they have root nodule bacterial association. Ironis an essential nutritional element for living organisms which is involved to play pivotal roles in various cellular, metabolic processes, especially synthesis of chlorophyll, photosynthesis and respiration. It is an important element for all living organisms due to its redox properties. Iron acts as a cofactor to carryout various biological functions like photosynthesis, electron transfer, oxygen transport, heme and chlorophyll biosynthesis, regulation of protein stability. The optimum range of $\mathrm{Fe}$ required by the plants varied between $10^{-4}$ and $10^{-8} \mathrm{M}$. Any variation in this range can deleteriously affect the plant growth and development resulting various metabolic disorders. Iron is abundantly available in soil but due to its low solubility it is often a limiting nutrient for plant growth. However, when $\mathrm{Fe}$ is highly accumulated in plant cells it becomes highly toxic and acts catalytically via
Fenton reaction, generates hydroxyl radicals which can damage lipids, DNA and protein. Therefore, plants must respond to Fe stress both excess and deficiency. A phenomenon known as stress induced morphogenic response occurs when plants comes in contact with stress responds by changing the root architecture of plants by altering its length, number as well as formation of root hair growth as roots are the primary organs which comes in contact with stress(Li et al. 2015). Fe excess arrests the primary root growth and inhibit the formation of lateral roots. However, in Fe deficiency plants enlarges their root surface area and it triggers the formation of root hairs. The roots can grow well in moderate $\mathrm{Fe}$ but drastically reduces in low or no Fe content. Bronzing is one of the major symptoms of $\mathrm{Fe}$ toxicity in plants which starts from the tip of the leaves and gradually spreads throughout the entire surface of the leaves and interveinal chlorosis is prominent in iron deficient plants (Dey et al. 2019). The objective of the study is to compare the iron stress response both in iron overload and in deficient condition in black gram and to evaluate their morphological, physiological and biochemical parameters at an early seedling stage. 


\section{MATERIALS AND METHODS}

The required seeds of two black gram cultivars (IPU-073 and Shekhar-1)were surface sterilized by $0.01 \%$ of $\mathrm{HgCl}_{2}$ (w/v) for about $4-5$ minutes. The treated seeds were rinsed properly for 5-6 times with distilled water and were kept imbibe in water soaked cotton for 8 hours and then the seeds were transferred to petri-plates with water soaked cotton beds at $30^{\circ} \mathrm{C}$ for germination. After 2 days old healthy seedlings were transplanted into plastic container holding Hoagland nutrient solution at $\mathrm{pH} 6.2$ and kept in growth chamber at $32^{\circ} \mathrm{C}$ with 16 hours light and 8 hours of dark photoperiodic condition and light illumination at $52 \mu \mathrm{mol} / \mathrm{m} / \mathrm{s}$. The nutrient solution was renewed after 2 days. On the $5^{\text {th }}$ day, three concentrations were selected viz., control at $\mathrm{pH}$ 6.2, iron excess $(2 \mathrm{mM})$ at $\mathrm{pH} 4.5$, and iron deficient $(10 \mu \mathrm{M})$ at $\mathrm{pH} 7.5$. Five plants were randomly selected from the growth medium for the measurement of both root and shoot in centimeter scale. Fresh weight of these five plants was also scored. Both root and shoots were oven dried at $72^{\circ} \mathrm{C}$ for 4 days and their dry weight was measured. The extent of lipid peroxidation was quantified in terms of MDA content following Heath and Packer (1968). The total $\mathrm{H}_{2} \mathrm{O}_{2}$ content was estimated following the method described by Sagisaka (1976). The total $\mathrm{O}_{2}{ }^{-}$content was estimated following the method described by Elstner and Heupul (1976).Chlorophyll estimation was performed using Arnon et al. (1949) method. All data was evinced as mean $(n=3)$ followed by standard error (mean \pm SE) format using SPSS 21 (window version) software. Along with the difference among the various treatments was determined by employing two-way ANOVA (analysis of variance) and post hoc Tukey's HSD (honest significant difference) test at 0.05 level of significance.

\section{RESULTS AND DISCUSSION}

\section{Growth attributes}

When abiotic stress hits seedling and vegetative phase of plants, it could negatively impact the growth affecting its morphological and physiological changes. During early seedling stage, stress reduces plant height as well as its total biomass (Asch et al. 2005). In both (2mM and $10 \mu \mathrm{M}) \mathrm{Fe}$-condition, the roots and shoots of the plant were significantly reduced $(p<0.001)$. Plants were exposed to stress for 72 hours and they have inhibitory effect on their growth. Decline in overall growth of plants was observed at 24, 48 and 72 hours, respectively. This could be due to the shrinkage of the tissue under stress. The reductions in fresh and dry weight (DW) of IPU-073 were significantly higher than

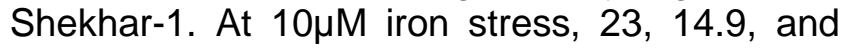
$20.7 \%$ root growth inhibition and $19.7,18.2$, and $19.1 \%$ shoot growth inhibition at 24,48 and 72 hours was observed in IPU-073, respectively as compared with control. The corresponding reductions in the root growth $(18.3,14.3$, and $14.2 \%)$ and shoot growth $(17.3,16.9$, and $14.9 \%$ ) at 24,48 and 72 hours respectively were recorded as compared with control (Table 1). The total growth inhibition was significantly

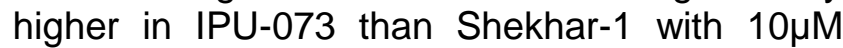
than the plant grown under $2 \mathrm{mM}$ iron stress. Plants in both concentrations of iron $(10 \mu \mathrm{M}$ and $2 \mathrm{mM}$ ) were affected by the amount of Fe present in their growth medium in comparison to the control plants. Similar kinds of results were obtained by Nenova, (2009) in pea plants under iron stress.

Table 1: Effect of deficient and excess iron on the root length and shoot length $(\mathrm{cm})$ in black gram

\begin{tabular}{|c|c|c|c|c|c|c|c|}
\hline \multirow{2}{*}{ Variety } & \multirow{2}{*}{$\begin{array}{l}\mathrm{Fe}^{2+} \\
\text { Conc. }\end{array}$} & \multicolumn{2}{|c|}{$24 \mathrm{Hrs}$} & \multicolumn{2}{|c|}{$48 \mathrm{Hrs}$} & \multicolumn{2}{|c|}{$72 \mathrm{Hrs}$} \\
\hline & & Root & Shoot & Root & Shoot & Root & Shoot \\
\hline \multirow{3}{*}{ IPU-073 } & Control & $10.56 \pm 0.11$ & $12.47 \pm 0.14$ & $10.90 \pm 0.37$ & $12.86 \pm 0.10$ & $12.50 \pm 0.07$ & $13.26 \pm 0.83$ \\
\hline & $2 \mathrm{mM}$ & $8.94 \pm 0.23^{\star * \star}$ & $11.02 \pm 0.94$ & $9.78 \pm 0.22$ & $11.76 \pm 0.15$ & $11.72 \pm 0.13$ & $11.98 \pm 0.09$ \\
\hline & $10 \mu \mathrm{M}$ & $8.12 \pm 0.27^{\star * *}$ & $10 \pm 0$ & $9.3 \pm 0.11$ & $9.90 \pm 0$ & $10.90 \pm 0.06^{* * *}$ & $10.72 \pm$ \\
\hline \multirow{3}{*}{$\begin{array}{c}\text { Shekhar- } \\
1\end{array}$} & Control & $12.19 \pm 0.59$ & 14. \pm( & $12.29 \pm 0.62$ & 16.25 & $12.9 \pm 0.32$ & $17.60 \pm 0.37$ \\
\hline & $2 \mathrm{mM}$ & $11.3 \pm 0.06$ & $12.86 \pm 0.10$ & $11.78 \pm 0.44$ & $14.09 \pm 0.39^{* *}$ & $11.95 \pm 0.46$ & $16.28 \pm 0.44$ \\
\hline & $10 \mu \mathrm{M}$ & $9.96 \pm 0.27^{\star \star \star}$ & $11.81 \pm 0.26^{*}$ & $10.53 \pm 0.36^{*}$ & $13.49 \pm 0.39^{* \star *}$ & $11.06 \pm 0.24^{* *}$ & $14.96 \pm 0.30^{*}$ \\
\hline & & \multicolumn{2}{|c|}{ Source of Variation } & \multicolumn{4}{|c|}{$F$-value } \\
\hline \multicolumn{2}{|c|}{ Variety } & $80.57^{* * *}$ & $21.44^{* * *}$ & $26.05^{\star \star \star}$ & $170.42^{\star \star \star}$ & $7.76^{\star *}$ & $134.27^{\star * *}$ \\
\hline \multicolumn{2}{|c|}{ Stress } & $17.61^{* * *}$ & $13.31^{* \star *}$ & $7.63^{* *}$ & $45.03^{\star * *}$ & $36.42^{* * *}$ & $16.21^{* * *}$ \\
\hline \multicolumn{2}{|c|}{ Variety $\mathrm{x}$ Stress } & 0.85 & 4.16 & 0.48 & 1.93 & 1.79 & 0.07 \\
\hline
\end{tabular}


The total biomass significantly declined after each 24 hours (24, 48 and 72 hours). The decline in FW of IPU-073 at $10 \mu \mathrm{M}$ was recorded as $33,33.9$, and $33.6 \%$ in roots at 24,48 and 72 hours respectively. In $2 \mathrm{mM}$ iron concentration, the decline FW rate in IPU-073 roots was 17.5, 13.3 and $15.9 \%$, respectively (Table 2 ). The decline rate was comparatively lower in the roots of Shekhar under $10 \mu \mathrm{M}$ and $2 \mathrm{mM}$ iron concentrations. Similar results were found in the shoots of both the blackgram varieties. Dry weight reduction was significantly higher in the roots and shoots of IPU-073 at $10 \mu \mathrm{M}$ than Shekhar-1 (Table 2). From the growth pattern it was evident that the root and shoot lengths of plant grown in $10 \mu \mathrm{M}$ were much lower than the control as well as from $2 \mathrm{mM}$ iron concentration. Similarly, the total biomass including fresh weight and dry weight of the plants decreased with iron toxicity and deficiency in comparison to control. Similar result was found in pea (Jelali et al. 2011). Not much work has been reported in iron deficiencies till now in case of pulse crops. However, according to recent reports, Fe acts a limiting factor for biomass production and yield in crops like Oryza sativa, Solanumly copersicum and Spinaciaoleracia (Briat and Gaymard, 2015). On the other hand, excess ferrous ion in the medium can accelerate the Fenton reaction releasing many oxidative particles which can lead to cell and tissue death (Morrisey and Guerinot, 2009). Therefore, under both fluctuating conditions of iron can affect the physiology of plants. Similar results were observed in the present study with decreased dry weight under both conditions for the genotypes.

Table 2: Effect of deficient and excess iron on fresh and dry weight $(\mathrm{g})$ of roots and shoots in blackgram

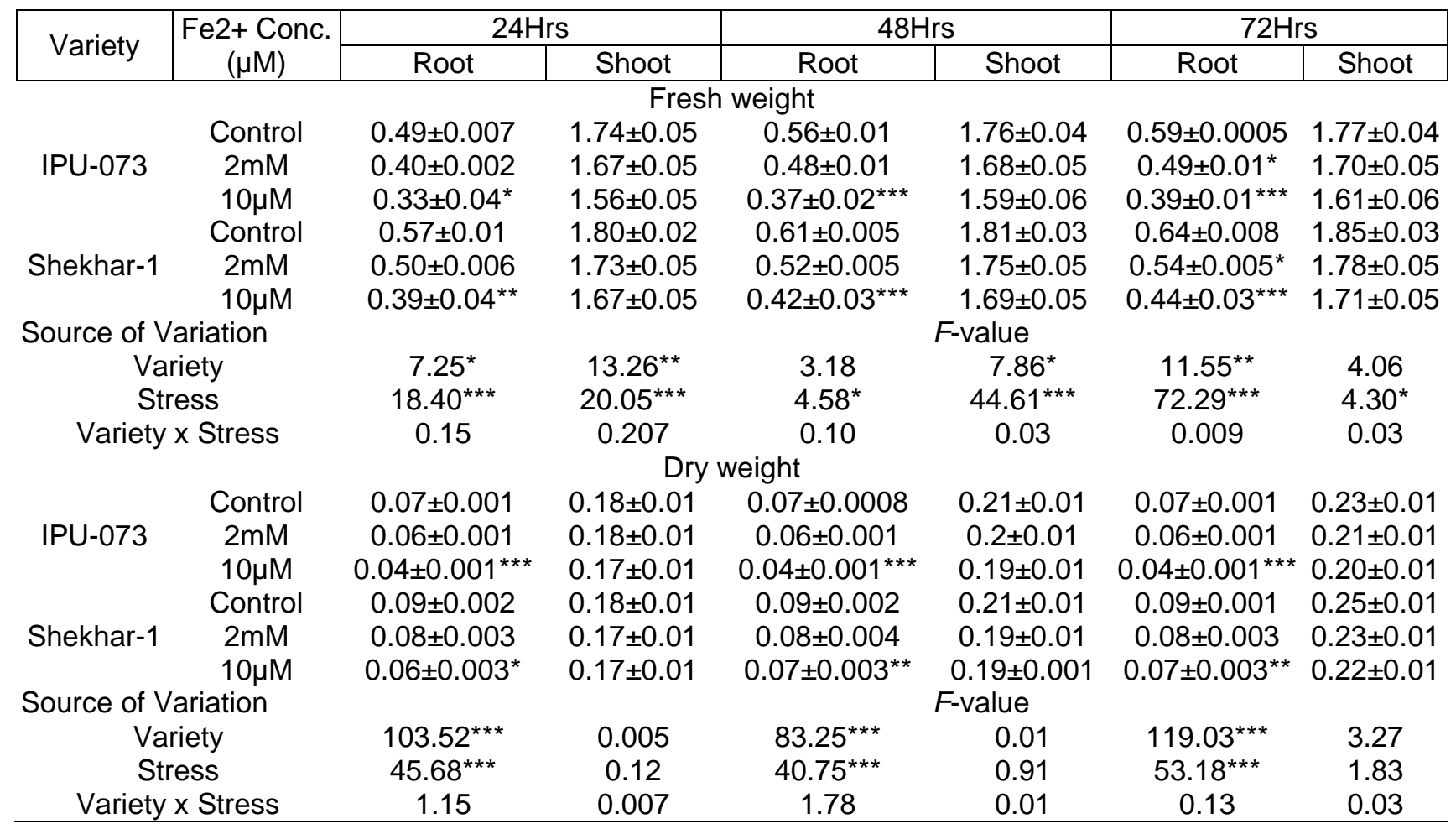

\section{Biochemical analysis}

Lipid peroxidation is one of the consequences of oxidative stress and thus production of Malondialdehyde (MDA) can be used as an indicator of lipid injury caused by oxidative stress. Higher MDA content was recorded in the roots (76\%) and leaves (82.2\%) of IPU-073under $10 \mu \mathrm{M}$ iron dose. Shekhar-1 reported to produce only $26.8 \%$ and $73.1 \%$ in the roots and leaves respectively at $10 \mu \mathrm{M}$ iron dose, as compared to control (Table 3). Hydrogen peroxide $\left(\mathrm{H}_{2} \mathrm{O}_{2}\right)$ production was significantly higher in the roots and leaves of 
IPU-073 at $10 \mu \mathrm{M}$ than $2 \mathrm{mM}$ iron concentration. In IPU-073, $\mathrm{H}_{2} \mathrm{O}_{2}$ content was recorded higher by $88.3 \%$ and $87.1 \%$ at $10 \mu \mathrm{M}$ and $87.1 \%$ and $67.9 \%$ at $2 \mathrm{mM}$ in the roots and leaves, respectively as compared to control. Similarly, in Shekhar-1, $70.5 \%$ and $79.4 \%$ at $10 \mu \mathrm{M}$ and $67.9 \%$ and $54.1 \%$ increase in $2 \mathrm{mM}$ in the roots and leaves respectively as compare with control. The data clearly indicated that excessive $\mathrm{H}_{2} \mathrm{O}_{2}$ production was found in IPU-073 than Shekhar-1 in both stress conditions (Table 3). Generation of superoxide radical $\left(\mathrm{O}_{2}^{-}\right)$under iron stress condition also showed similar result like $\mathrm{H}_{2} \mathrm{O}_{2}$ which was significantly higher in the roots and shoots of IPU-073 at $10 \mu \mathrm{M}$ that at $2 \mathrm{mM}^{-\mathrm{O}_{2}}{ }^{-}$ content of $50.1 \%$ was found in the roots of IPU073 at $10 \mu \mathrm{M}$ which was only $36.6 \%$ recorded in the roots of shekhar-1. Similarly, $60.9 \% \quad \mathrm{O}_{2}{ }^{-}$ content was found in the leaves of IPU-073 which was higher than $49.4 \%$ in the leaves of
Shekhar-1 at $10 \mu \mathrm{M}$ (Table 3). The evaluation of MDA, $\mathrm{H}_{2} \mathrm{O}_{2}$ and $\mathrm{O}_{2}^{-}$concentration showed that these reactive species were strongly enhanced in iron deficient condition with highest value in IPU-073 in comparison to control and iron excess. Therefore, the result obtained from the experiment indicates that plants generate more ROS in iron starvation. Leguminous plants are great source of antioxidants like ascorbates and glutathiones in their root nodules. These provide antioxidant defense against number of oxidative damage. However, excess of transition metals like $\mathrm{Fe}^{2+}$ in the tissues leads to formation of peroxide and superoxide radicals (Moran et al, 2015). In the present work, excess Fe at $2 \mathrm{mM}$ produced similar results with higher peroxide and MDA content. Similar kind of observation was also recorded in other crops such asrice (Kar et al. 2019).

Table 3: MDA content, $\mathrm{H}_{2} \mathrm{O}_{2}$ content and Superoxide radical $\left(\mathrm{O}_{2}^{-}\right)(\mu \mathrm{M} \mathrm{g}-1 \mathrm{FW})$ in blackgram roots and leaves under iron deficit and excess stress condition at 48 hours

\begin{tabular}{|c|c|c|c|c|c|c|c|}
\hline \multirow{2}{*}{ Variety } & \multirow{2}{*}{$\begin{array}{l}\text { Fe2+ } \\
\text { Conc. }\end{array}$} & \multicolumn{2}{|c|}{ MDA } & \multicolumn{2}{|c|}{$\mathrm{H}_{2} \mathrm{O}_{2}$} & \multicolumn{2}{|c|}{$\mathrm{O}_{2}^{-}$} \\
\hline & & Root & Leaves & Root & Leaves & Root & Leaves \\
\hline \multirow{3}{*}{ IPU-073 } & Control & $0.14 \pm 0.02$ & $0.14 \pm 0.05$ & $0.11 \pm 0.009$ & $0.062 \pm 0.008$ & $2.29 \pm 0.01$ & $2.08 \pm 0.008$ \\
\hline & $2 \mathrm{mM}$ & $0.35 \pm 0.01^{* *}$ & $0.41 \pm 0.05^{\star *}$ & $0.91 \pm 0.02^{\star \star \star}$ & $0.19 \pm 0.03^{* *}$ & $3.70 \pm 0.20^{*}$ & $3.98 \pm 0.59^{* *}$ \\
\hline & $10 \mu \mathrm{M}$ & $0.59 \pm 0.07^{\star * *}$ & $0.83 \pm 0.03^{\star * *}$ & $1.00 \pm 0.08^{* \star *}$ & $0.48 \pm 0.009^{* * *}$ & $4.61 \pm 0.38^{\star \star \star}$ & $5.33 \pm 0.33^{* * *}$ \\
\hline \multirow{3}{*}{$\begin{array}{c}\text { Shekhar- } \\
1\end{array}$} & Control & $0.15 \pm 0.27$ & $0.14 \pm 0.001$ & $0.15 \pm 0.002$ & $0.07 \pm 0.002$ & $2.44 \pm 0.09$ & $2.10 \pm 0.05$ \\
\hline & $2 \mathrm{mM}$ & $0.19 \pm 0.14$ & $0.34 \pm 0.02^{*}$ & $0.47 \pm 0.02^{* *}$ & $0.15 \pm 0.01$ & $3.11 \pm 0.25$ & $3.46 \pm 0.21$ \\
\hline & $10 \mu \mathrm{M}$ & $0.21 \pm 0.005$ & $0.54 \pm 0.03^{* *}$ & $0.51 \pm 0.02^{\star * *}$ & $0.34 \pm 0.03^{\star * \star}$ & $3.86 \pm 0.26^{*}$ & $4.16 \pm 0.11^{\star *}$ \\
\hline \multicolumn{2}{|c|}{ Source of Variation } & & & & $F$-value & & \\
\hline \multicolumn{2}{|c|}{ Variety } & $40.54^{* * *}$ & $13.79^{\star \star \star}$ & $83.33^{* * *}$ & $12.01^{\star *}$ & 4.20 & $5.39^{*}$ \\
\hline \multicolumn{2}{|c|}{ Stress } & $29.36^{\star \star *}$ & $95.16^{\star \star *}$ & $145.28^{\star * *}$ & $149.13^{\star * *}$ & $31.29^{* \star *}$ & $41.04^{\star \star *}$ \\
\hline \multicolumn{2}{|c|}{ Variety $\times$ Stress } & $17.51^{\star \star *}$ & $7.15^{\star \star \star}$ & $25.93^{\star \star \star}$ & $6.88^{\star \star}$ & 2.04 & 2.06 \\
\hline
\end{tabular}

Excessive ROS yield can lead to the chlorophyll breakdown. Chlorosis and bronzing are the two phenomenon which becomes visible on the surface of the leaves when plants are exposed to iron deficiency and excess respectively which indicates the onset of the oxidative stress. Chlorophyll content are regarded as the stress induced biomarker which can help in the evaluation of stress induced toxicity in field crops. Total chlorophyll and carotenoid content decreased significantly in both IPU-073 and Shekhar-1 under 10 $\mu \mathrm{M}$ than $2 \mathrm{mM}$ of iron doses. The decline rate of total $\mathrm{Chl}$ was $46.4 \%$ in IPU-073 and only $10 \%$ decline was recorded in Shekhar-1 under $10 \mu \mathrm{M}$ of iron stress. A decline of $44.3 \%$ and $17.6 \%$ in carotenoid content was recorded in the leaves of IPU-073 and Shekhar-1 respectively under $10 \mu \mathrm{M}$. However, there was less decline rate recorded in plants grown under $2 \mathrm{mM}$ iron concentration (Table 4). Total chlorophyll and carotenoid content were found higher in Shekhar-1 than IPU-073 indicating relatively tolerance against oxidative stress. Similar kind of results was also found in green gram (Verma and Pandey, 2017), groundnut (Mann et al. 2017). 
Table 4: Chlorophyll a, chlorophyll b, total chlorophyll and carotenoid content $\left(\mathrm{nM} \mathrm{g}^{-1} \mathrm{Fw}\right)$ in blackgram roots and leaves under iron deficit and excess stress condition at 48 hours

\begin{tabular}{|c|c|c|c|c|c|}
\hline Variety & $\mathrm{Fe}^{2+}$ Conc. & Chl $a$ & Chl $b$ & Total Chl & Carotenoid \\
\hline \multirow{5}{*}{ Shekhar-1 } & $2 \mathrm{mM}$ & $11.57 \pm 0.22^{\star \star *}$ & $6.94 \pm 0.16^{\star}$ & $18.69 \pm 0.32^{\star \star *}$ & $1.06 \pm 0.01^{* * \star}$ \\
\hline & $10 \mu \mathrm{M}$ & $9.80 \pm 0.45^{\star * *}$ & $4.75 \pm 0.73^{\star \star \star}$ & $14.70 \pm 0.70^{\star * *}$ & $0.82 \pm 0.04^{* * *}$ \\
\hline & Control & $16.69 \pm 0.82$ & $10.14 \pm 0.29$ & $21.18 \pm 0.45$ & $1.40 \pm 0.09$ \\
\hline & $2 \mathrm{mM}$ & $14.27 \pm 0.24^{*}$ & $7.26 \pm 0.22^{* *}$ & $19.76 \pm 0.47^{*}$ & $1.18 \pm 0.02^{*}$ \\
\hline & $10 \mu \mathrm{M}$ & $12.55 \pm 0.25^{\star * *}$ & $7.01 \pm 0.27^{\star \star \star}$ & $19.57 \pm 0.47^{\star}$ & $1.16 \pm 0.007^{*}$ \\
\hline \multicolumn{2}{|c|}{ Source of Variation } & $F$-value & & & \\
\hline \multicolumn{2}{|c|}{ Variety } & $14.96^{* * *}$ & $17.21^{\star \star *}$ & 0.07 & $11.59^{* \star}$ \\
\hline \multicolumn{2}{|c|}{ Stress } & $116.03^{* * *}$ & $53.70^{* * *}$ & $222.40^{\star * *}$ & $54.31^{* * *}$ \\
\hline \multicolumn{2}{|c|}{ Variety $\times$ Stress } & $16.32^{\star * *}$ & 3.59 & $107.20^{\star * *}$ & $10.45^{\star \star}$ \\
\hline
\end{tabular}

It may be concluded from the results, that iron deficit or excess conditions drastically reduced the plant growth and accumulation of biomass stimulate chlorosis and oxidative stress especially iron deficit condition. The results clearly indicated that Shekhar-1 showed minimized oxidative damage rather than IPU-073 due to the better defense mechanism against both iron deficiency and excess conditions.

\section{REFERENCES}

Arnon, D.I. (1949) Copper enzymes in isolated chloroplasts, polyphenoxidase in betavulgaris. Plant physiology 24:1-15.

Asch, F., Becker, M. and Kpongor, D.S. (2005) A quick and efficient screen for resistance to iron toxicity in lowland rice. Journal of Plant Nutrition and Soil Science 168: 110

Briat, J. F., Dubos, C., and Gaymard, F. (2015) Iron nutrition, biomass production, and plant product quality. Trends in Plant Science 20 (1): 33-40.

Dey, S., Kar, S., Regon, P. and Panda, S.K. (2019) Physiology and biochemistry of fe excess in acidic asian soils on crop plants. Journal of Soil Science and Agroclimatology 16 (1): 112-126.

Elstner, E. F. and Heupel, A. (1976) Formation of hydrogen peroxide by isolated cell walls from horseradish (Armoracia lapathifolia Gilib.). Planta 130(2): 175-80.

Heath, R.L. and Packer, L. (1968) Photoperoxidation in isolated

\section{ACKNOWLEDGEMENT}

We sincerely acknowledge Indian Institute of Pulses Research, Kanpur, India for supplying black gram seeds. This research was financed from the fellowship obtained from Department of Science and Technology Innovation in Science Pursuit for Inspired Research (DST- INSPIRE), Government of India, No. DST/INSPIRE Fellowship/2016/IF160804, Dated 12.02.2018.

chloroplasts: I. Kinetics and stoichiometry of fatty acid peroxidation. Archives of Biochemistry and Biophysics 125 (1): 189-198.

Jelali, N., Salah, I.B., M'sehli, W., Donnini, S., Zocchi, G. and Gharsalli, M. (2011) Comparison of three pea cultivars (Pisumsativum) regarding their responses to direct and bicarbonateinduced iron deficiency. Scientia Horticulturae 129 (4): 548-553.

Kar, S., Goswami, S., Borgohain, P and Panda, S.K. (2019) Differential responses by upland and lowland cultivars of rice (Oryza sativa L.) under iron toxicity. Annals of Plant and Soil Research 21 (3): 226-232.

Li, G., Xu, W., Kronzucker, H.J. and Shi, W. (2015) Ethylene is critical to the maintenance of primary root growth and $\mathrm{Fe}$ homeostasis under $\mathrm{Fe}$ stress in Arabidopsis. Journal of experimental botany 66 (7): 2041-2054. 
Mann, A., Singh, A.L., Oza, S., Goswami, N., Mehta, D., and Chaudhari, V. (2017). Effect of iron source on iron deficiency induced chlorosis in groundnut. Legume Research- An International Journal $\mathbf{4 0}$ (2): 241-249.

Moran, J.F., Klucas, R.V., Grayer, R.J., Abian, J., and Becana, M. (1997) Complexes of iron with phenolic compounds from soybean nodules and other legume tissues: prooxidant and antioxidant properties. Free Radical Biology and Medicine 22 (5), 861-870.

Morrissey, J., and Guerinot, M.L. (2009) Iron uptake and transport in plants: the good, the bad, and the ionome. Chemical reviews 109 (10): 4553-4567.

Nenova, V.R. (2009) Growth and photosynthesis of pea plants under different iron supply. Acta Plantarum 31(2): 385.

Sagisaka, S. (1976) The occurrence of peroxide in perennial plant of Populas gelrica. Plant Physiology 57: 308-309.

Verma, L., and Pandey, N. (2017) The effect of iron toxicity on seed germination and early seedling growth of green gram (Vignaradiata L. Wilczek). International Journal of Science and Research 6: 1427-1430. 